\title{
The Features and Promotion of Excellent Course in Universities on the Basis of Cultivating Innovative Talents
}

\author{
Liangwei Lv \\ Yantai Nanshan University \\ Yantai, Shandong, China
}

\author{
Ming Xue \\ Yantai Nanshan University \\ Yantai, Shandong, China
}

\begin{abstract}
The excellent course construction requires teaching contents to reflect the requirements of standards of talented person and pay attention to adaptation; reflect academic forelands and pay attention to advancement; introduce the newest discipline achievement in development and pay attention to update; correctly arrange and design theory contents and practical contents and pay attention to the links. The construction and promotion of teaching contents of excellent courses is a very important content of building excellent courses, using excellent courses to research, drive and promote the teachers to attach importance to teaching, do research on teaching, strengthen the quality of teaching to significantly improve the quality of talents cultivation.
\end{abstract}

Keywords-excellent course; features; innovation; promotion

\section{INTRODUCTION}

The course construction of institution of higher learning should closely centre on the basic task of talent cultivation of higher education to promote the professional construction and improve the quality talent cultivation. We should give full play to the demonstration and driving effect of the existing excellent course and set up the course constructive awareness of the team, integrate excellent educational resources, reform teaching content, improve teaching method, strengthen teaching conditions, optimize allocation of resources to promote obvious improvement of quality of the talents cultivation of higher education.

From the aspect of course orientation, excellent course should be famous course, model course with its own characteristics and style. Specifically speaking, excellent course refers to the excellent course with features and firstclass teaching level. Its construction should base on talent cultivation objectives, reflect modern education thought, and conform to the universal rule of scientific nature, advancement, education and teaching, have distinct features and can appropriately apply modern education technology and method, make the teaching efficiency obvious and have unique features and the effect of innovation, radiation and promotion.

\section{THE FEATURE AND INNOVATION OF EXCELLENT COURSE IN UNIVERSITIES ARE THE GOALS OF CONSTRUCTION}

\section{A. The Construction of Feature and Innovation of Excellent Course in Universities Is the Embodiment of the "Quality" of Excellent Course}

Since the Ministry of Education has started the construction of excellent course in 2003, under the lead of excellent course construction, universities have made plentiful and substantial achievements in the aspects such as the course construction promotion, the construction of teaching staff, teaching conditions construction. The important role and status of excellent course construction have been universally accepted inside higher education. In the present evaluation, whether institution of higher learning has a group of high level excellent course which reflects the academic foreland is an important symbol to measure the academic level, teaching level and education quality of a school. However, when carefully examine the current situation of excellent course construction, we as well find a lot of problems while affirming the achievements. A good deal of excellent course cannot grasp the connotation of excellent course in the construction and lack the educational spirit of "putting students first" of excellent course. The tendencies such as utilitarianism, formalism and bringism restrict the further in-depth development of excellent course.

In 2003, Notification of the Ministry of Education about Starting the Excellent Course Construction Work of Teaching Quality and Teaching Reform Project of Institution of Higher Learning points out: excellent course is model course with the features of having first-class teaching body, first-class teaching content, first-class teaching method, firstclass teaching material, first-class teaching management. Since 2009, the description of excellent course evaluation indicator has changed "Excellent course refers to the excellent course with features and first-class teaching level. According to the talent cultivation objective, excellent course construction should reflect modern education thought, conform to the universal rule of the scientific nature, advancement and education and teaching, has distinct features and can appropriately apply modern education 
technology and method, make the teaching efficiency obvious and have the effect of innovation, radiation and promotion."

\section{B. The Promotion of Feature and Innovation of Excellent Course in Universities Is the Effect of the "Quality" of Excellent Course}

The first and foremost goal of excellent course construction is to promote the open and sharing of excellent educational resources. So the mechanism perfect degree of promotion, utilization and sharing is a significant symbol to measure whether excellent course construction can succeed or not.

About the promotion mechanism of excellent course, we should need to do on publicizing and promoting teaching resources: first, survey and analyze the requirements of teachers and students; second, give lecture to or train teachers and students how to use teaching resources effectively; third, fully arouse teachers' and students' enthusiasm to participate in the works of resource construction, communication and evaluation to reflect their subjectivity.

About the utilization mechanism of excellent course, we should set up effective utilization mechanism of excellent course resources, guide students to make full use of high quality resources, build utilization system of excellent course, complete the material basis of excellent course resources utilization, deepen students' understanding of excellent course and cultivate students' awareness of using.

\section{THE CONSTRUCTION OF FEATURES AND INNOVATION OF EXCELLENT COURSE IN UNIVERSITIES}

\section{A. The Construction of Features of Excellent Course in Universities}

Feature is the attribute of excellent course and course without features cannot become excellent course. The construction of any course must abide by its own internal logic and rule. If breaking away from objective reality and blindly following or copying others, course construction maybe will become a kind of fickleness with numerous sounds clamor and become a mere formality. Excellent course is a comprehensive carrier which bears the connotation such as the school-running orientation, specialty orientation, teachers' level, teaching idea, teaching contents, teaching resources, teaching management and the quality of students. So each excellent course should have its own features and there isn't absolute the same standard and the same pattern.

Feature is the style and form of a thing or a kind of things obviously different from other things, determined by the certain specific environmental factors for the production and development of things, and it is only possessed by the thing that it belongs to. Different schools have different features of discipline and specialty to form course system with different characteristics. So excellent course should be multi-level and diversification and have distinct features. This kind of feature can reflect on aspects such as the rich and colorful course content, novel teaching model, prominent internship and practical training, remarkable teaching effect, website design with distinct personality, etc.

The features of excellent course reflect the unique style formed by a school, a specialty, a teaching team in the longterm school-running and course construction. The cultivation of excellent course feature is a difficult and systematic project and involves the aspects such as teaching facilities, teachers, teaching method and teaching management, etc. Various universities should base on the age characteristic, regional background, and the actual situation of the schools, determine the ideas and content of the characteristic construction of excellent course to make it adapt the school orientation and talent training goal, match with the preponderant discipline and featured specialty, set up relatively complete course feature development system and improve in practice.

\section{B. The Construction of Innovation of Excellent Course in Universities}

Innovation is a conceptual process which has the features of new thinking, new invention and new description. There are three layers of its original meaning, first, update; second, to create something new; three, change. Innovation is a uniquely human cognitive ability and practice ability. It is a high-ranking manifestation of human subjective initiative and an inexhaustible motive force to promote national progress and social development. Excellent course construction is an innovative project. Its innovation mainly shows in the transformation of educational concept, the update of teaching content, the change of teaching method and means, the improvement of way and their organic integration.

We should firstly update educational thought, transform education concept and set up new curriculum view in the excellent course construction. Teachers in universities should carefully implement the Party's educational policy, constantly deepen educational reform, and run through modern education concepts such as people oriented, integrated development, quality-oriented education, creativity, subjectivity, openness, systematicness, individuation and diversification, etc., correctly grasp the relations between knowledge teaching, ability cultivation and the quality improvement; we should put education first, quality first on the core location to plan and reflect the "teacher-directed and student subject" and "student-oriented" course system, teaching content, teaching method and means, course materials and teaching environment construction, etc. There is a high demand of construction of university teachers. It not only needs schools to organize regular education theoretical study, but also supervises and urges teachers to carry on the teaching reflection to improve their teaching abilities.

The construction and update of the teaching content of excellent course is a very important content in excellent course construction. At present, the teaching contents of many colleges and universities seriously lag behind the requirements of industry development, especially lag far 
behind international development level, lead to the fact that students have fallen behind the market requirements before employment. The excellent course construction requires teaching contents to reflect the requirements of standards of talented person and pay attention to adaptation; reflect academic forelands and pay attention to advancement; introduce the newest discipline achievement in development and pay attention to update; correctly arrange and design theory contents and practical contents and pay attention to the links. The update of teaching content of excellent course mainly sees whether it has "three-dimensional" teaching material which can reflect the latest teaching reform achievements and scientific and technological level of the industry, whether the curriculum standards and the design scheme of teaching are scientific and advanced with reasonable arrangement and meet the requirements of students' knowledge, ability and quality training target. The organization form of teaching content which can make theory link with practice, link the in class with outside class; integrate knowledge teaching, ability cultivation and qualityoriented education is an important indicator to measure the teaching level of teaching staff and as well a key that a course can really become high level excellent course.

\section{THE PROMOTION OF EXCELLENT COURSE RESOURCES IN UNIVERSITIES}

The first and foremost goal of excellent course construction is to promote the open and sharing of excellent educational resources. So the mechanism perfect degree of promotion, utilization and sharing is a significant symbol to measure whether excellent course construction can succeed or not. According to the talent cultivation objective, excellent course construction should reflect modern education thought, conform to the universal rule of the scientific nature, advancement and education and teaching, has distinct features and can appropriately apply modern education technology and method, make the teaching efficiency obvious and have the effect of innovation, radiation and promotion.

Building up effective resources utilization mechanism of excellent course and guiding students to make full use of resources of high quality needs to build utilization system of excellent course, complete the material basis of the resources utilization of excellent course, and deepen students' understanding of excellent course and train students' awareness of utilization. We should accelerate the progress of the integration project of excellent course, establish sharing platform of excellent course as soon as possible to realize the rapid access for course content and active service of individuation and make all non-commercial users can share resources whenever and wherever possible and strengthen the mechanism research on the sharing policy of excellent course.

The utilization of research achievements of excellent course drives and promotes the entire school teachers to attach great importance to the teaching, research teaching and strengthen teaching quality to make quality of the talents cultivation improve significantly. We should apply the teaching characteristics and innovation in excellent course research to professional teaching and make teachers initiatively update their teaching concept to adapt the requirements of teaching and the popularization of higher education. Using research achievements as teachers' teaching concept to apply to the class teaching activities plays an important guiding role in location of talent training, choice of pattern, the view of quality of higher education, the establishment of quality standard, especially the curriculum provision which can meet students' development and the requirements of the society.

\section{REASONABLE CONSTRUCTION AND PLANNING OF EXCELLENT COURSE IN UNIVERSITIES}

\section{A. "People Oriented, Teachers and Students Making Joint Efforts to Build"'of Excellent Course}

Excellent course construction is the day-to-day work to improve the quality of college talents training. We should set up the consciousness for the best and reflect the principle of "people oriented". On one hand, we should make great efforts to create an environment suitable for teachers to peacefully create competitive products and raise teachers' enthusiasm to participate in the excellent course construction to make an excellent teacher team. On the other hand, we should give full play to students' main boy effect, understand students' knowledge structure and advocate the design mode of "learning-centered" to design teaching content. We cannot only emphasize class capacity and neglect students' rule of thinking process.

\section{B. "Paying Attention to the Connotation and Displaying Vividly" of Excellent Course}

Connotation construction is the core work of excellent course. Under the direction of modern education theory, through the joint efforts of teachers, students and wellknown experts and professors, we should make each material become excellent material, make each courseware become excellent courseware, make each website become excellent website, make each lesson become excellent lesson, make each experiment become experiment, and solidly promote the connotation of excellent course through relaxing teaching environment, flexible teaching function, advanced teaching methods and exploratory teaching model.

\section{C. "Highlighting the Features and Combining Construction and Introduction" of Excellent Course}

Excellent course is the centralized reflection of characteristic specialty and discipline advantage of higher education teaching. Some famous universities at home and abroad pay much attention to the development and extraction of teaching features. There are highlights only when there are characteristics. These characteristics make some of their disciplines are at the forefront of the world and have a broad influence. Therefore, we should not tend to be the same but build excellent course with distinct characteristics according to course characteristics. The kind of characteristic can be the aspect of teaching concept as well as the teaching content. At the same time, when autonomously develop excellent teaching resource, we should as well broad the way of 
thinking, open our eyes to the whole world, actively introduce advanced teaching resources at home and abroad, improve the resource structure of excellent course to ensure the pith of course resources.

\section{D. “Group Investigation Model, Reflecting Innovation” of Excellent Course}

The model of teaching is under the guidance of certain teaching ideas and surrounds a topic of teaching activity to form relatively stable, systematic and theoretical teaching paradigm. The construction of excellent course teaching mode should surround the problem of "teachers how to teach and students how to learn". Excellent course teaching should pay more attention to transfer teaching form from the single classroom teaching to many forms of interactive communication. In accordance with its inherent rule, we need to explore and innovate continuously on the teaching methods in the aspects such as in class and outside class, theory and practice, books and the internet, campus and society, etc.

\section{E. "Standardized Management, Dynamic Development"of Excellent Course}

The excellent course construction is a time-consuming, laborious and complex work. Once being completed and put into use, it often has relative stability. However, because the era that we are in is information era, and knowledge updates frequently, and the speed of transmission accelerates, excellent course need to deal with the relationships between relative stability and timely update on the basis of standard management. It shouldn't be standstill after being completed and become outer part course and image project hang on the internet. On one hand, when excellent course constructs to a certain scale, the management layer must formulate comprehensive, effective and sustainable long-term development mechanism and evaluation system, constantly strengthen the connotation construction and make perfection more perfect. On the other hand, teachers shouldn't complete making the excellent course and put it into use once for all. They should make efforts to get the latest information, master the latest academic dynamic and timely add it to excellent course, consciously transfer academic research results into teaching content, expand the depth and breadth of teaching, improve the academic level of teaching, enrich the academic connotation of course to make excellent course teaching reflect stronger timeliness and pertinence.

\section{CONCLUSION}

Excellent course construction is national guidance and the foundation engineering to improve teaching quality. Its construction thoughts, process and requirements, evaluation system and the change of talents training mode triggered by it have added new vitality to university courses construction. Just as its name implies, excellent course is excellent course among course and it is the flag of course construction and plays a guiding and exemplary role in course construction. A professional main course has its own objective prescription no matter you admit it or not. But if it wants to go up to excellent course and reach the five "first class", it must design elaborately through solid construction and long term accumulation of teaching practice. We should use the results of research to promote the specialty construction and curriculum development and improve the effect of excellent course and teaching quality. Building effective resources utilization mechanism of excellent course and guiding students to make full use of resources of high quality needs to build the utilization system of excellent system, complete the material basis of the resource utilization of excellent course, deepen students' understanding for excellent course and cultivate students' awareness of utilization.

The utilization of research achievements of excellent course drives and promotes the entire school teachers to attach great importance to the teaching, research teaching and strengthen teaching quality to make quality of the talents cultivation improve significantly. We should apply the teaching characteristics and innovation in excellent course research to professional teaching and make teachers initiatively update their teaching concept to adapt the requirements of teaching and the popularization of higher education. Using research achievements as teachers' teaching concept to apply to the class teaching activities plays an important guiding role in location of talent training, choice of pattern, the view of quality of higher education, the establishment of quality standard, especially the curriculum provision which can meet students' development and the requirements of the society. 